\title{
MtDNA species-level phylogeny and delimitation support significantly underestimated diversity and endemism in the largest Neotropical cichlid genus (Cichlidae: Crenicichla)
}

\author{
Oldřich Říčan ${ }^{\text {Corresp., } 1}$, Klára Dragová ${ }^{1}$, Adriana Almirón ${ }^{2}$, Jorge Casciotta ${ }^{3,4}$, Jens Gottwald ${ }^{5}$, Lubomír Piálek ${ }^{1}$ \\ ${ }^{1}$ Faculty of Science, Department of Zoology, University of South Bohemia, České Budějovice, Czech Republic \\ 2 División Zoología Vertebrados, UNLP, Facultad de Ciencias Naturales y Museo, La Plata, Buenos Aires Province, Argentina \\ 3 CIC, Comisión de Investigaciones Científicas de la Provincia de Buenos Aires, Buenos Aires, Argentina \\ 4 UNLP, Facultad de Ciencias Naturales y Museo, División Zoología Vertebrados, Paseo del Bosque, La Plata, Buenos Aires Province, Argentina \\ 5 Heinrich-Lödding-Str. 14, 30823 Garbsen, Garbsen, Germany \\ Corresponding Author: Oldřich Říčan \\ Email address: oldrich.rican@prf.jcu.cz
}

Crenicichla is the largest and most widely distributed genus of Neotropical cichlids. Here, we analyze a mtDNA dataset comprising 681 specimens (including Teleocichla, a putative ingroup of Crenicichla) and 77 out of 105 presently recognized valid species (plus 10 out of 36 nominal synonyms plus over 50 putatively new species) from 129 locations in 31 major river drainages throughout the whole distribution of the genus in South America. Based on these data we make an inventory of diversity and highlight taxa and biogeographic areas worthy of further sampling effort and conservation protection. Using three methods of molecular species delimitation we find between 126 and 168 species-like clusters, i.e. an average increase of species diversity of $65-121 \%$ with a range of increase between species groups. The increase ranges from from $0 \%$ in the Missioneira and Macrophthama groups, through 25-40\% (Lacustris group), 50-87\% (Reticulata group, Teleocichla), $68-168 \%$ (Saxatilis group), 125-200\% (Wallacii group), and $158-241 \%$ in the Lugubris group. We found a high degree of congruence between clusters derived from the three used methods of species delimitation. Overall, our results recognize substantially underestimated diversity in Crenicichla including Teleocichla. Most of the newly delimited putative species are from the Amazon-Orinoco-Guiana (AOG) core area (Greater Amazonia) of the Neotropical region, especially from the Brazilian and Guiana shield areas of which the former is under the largest threat and largest degree of environmental degradation of all the Amazon. 
MtDNA species-level phylogeny and delimitation support significantly

underestimated diversity and endemism in the largest Neotropical cichlid genus (Cichlidae: Crenicichla)

"That we are seeing further is only because we are standing on the shoulders of giants. This study is dedicated to the giants among the cichlid hobbyists who have amazed great knowledge of Neotropical cichlids far surpassing the knowledge achieved by professional ichthyologists, who are plagued by lack of funding and appreciation for systematic biology and incredible red tape and bureaucracy apparently designed to specifically hinder the exploration of biodiversity."

\section{Running head:}

Species diversity in Crenicichla

\section{Authors:}

Oldřich Říčan ${ }^{1 *}$, Klára Dragová1, Adriana Almirón ${ }^{2}$, Jorge Casciotta ${ }^{2,3}$, Jens Gottwald ${ }^{4}$ \& Lubomír Piálek ${ }^{1}$

1-University of South Bohemia, Faculty of Science, Department of Zoology, Branišovská 31, 370 05, České Budějovice, Czech Republic.

2-UNLP, Facultad de Ciencias Naturales y Museo, División Zoología Vertebrados, Paseo del Bosque, 1900 La Plata, Buenos Aires Province, Argentina, 3-CIC, Comisión de Investigaciones Científicas de la Provincia de Buenos Aires.

4-Heinrich-Lödding-Str. 14, 30823 Garbsen, Germany

* corresponding author: oldrich.rican@prf.jcu.cz.

Email addresses: klara.dragova@gmail.com, lubomir.pialek@prf.jcu.cz, aalmiron@fcnym.unlp.edu.ar, jrcas@fcnym.unlp.edu.ar, aquatarium@t-online.de

\section{Abstract:}


32 Crenicichla is the largest and most widely distributed genus of Neotropical cichlids. 33 Here, we analyze a mtDNA dataset comprising 681 specimens (including Teleocichla, 34 a putative ingroup of Crenicichla) and 77 out of 105 presently recognized valid species 35 (plus 10 out of 36 nominal synonyms plus over 50 putatively new species) from 129 36 locations in 31 major river drainages throughout the whole distribution of the genus in 37 South America. Based on these data we make an inventory of diversity and highlight taxa and biogeographic areas worthy of further sampling effort and conservation protection. Using three methods of molecular species delimitation we find between 126 and 168 species-like clusters, i.e. an average increase of species diversity of $65-121 \%$ with a range of increase between species groups. The increase ranges from from $0 \%$ in the Missioneira and Macrophthama groups, through 25-40\% (Lacustris group), 5087\% (Reticulata group, Teleocichla), 68-168\% (Saxatilis group), 125-200\% (Wallacii group), and $158-241 \%$ in the Lugubris group. We found a high degree of congruence between clusters derived from the three used methods of species delimitation. Overall, our results recognize substantially underestimated diversity in Crenicichla including Teleocichla. Most of the newly delimited putative species are from the AmazonOrinoco-Guiana core area (Greater Amazonia) of the Neotropical region, especially from the Brazilian and Guiana shield areas of which the former is under the largest threat and largest degree of environmental degradation of all the Amazon.

\section{Key Words:}

freshwater fishes; endemism; putative new species; phylogeography; molecular-clock dating; conservation

\section{Introduction}

The cichlid family (Cichlidae) is an important family of Neotropical fishes that is the dominant group of larger sized fishes in Middle America (Myers, 1966; Bussing, 1976, 1985; Říčan et al., 2013, 2016) and the third richest family of fishes in South America (Van der Sleen and Albert, 2018). Crenicichla Heckel, 1840 is the most widely distributed and largest cichlid genus in South America and in the whole Neotropical biogeographic region (Ploeg, 1991; Piálek et al., 2012; Van der Sleen and Albert, 2018) 
63 and is the eighth richest fish genus in South America (Van der Sleen and Albert, 2018).

64 The Neotropical cichlids are members of the by far most diverse and extreme aquatic ecosystems on Earth and the largest community of freshwater fishes in the World with more than 5,600 valid species and with current estimates far exceeding 7,000 species, representing about 10\% all living vertebrate species (Reis et al., 2003; Albert and Reis, 2011; Van der Sleen and Albert, 2018).

Crenicichla species inhabit a wide range of virtually all cis-Andean (east of the Andes) South American water bodies (Stawikowski and Werner, 2004; Kullander et al., 2018) from small rainforest and mountain streams, medium through large rivers, lakes, floodplains and even marshes, living both in main channels as well as pools and riffles and even rapids, but generally few species are widely distributed or found in more than one type of habitat, with endemism, regionality, and habitat adaptations being strongly pronounced in this genus as well as in cichlids in general. Crenicichla are monogamous substratum spawning biparental fishes with a strong nest and fry protection and very long parental care (Stawikowski and Werner, 2004), even among the generally long parental care in cichlids in general (Stawikowski and Werner, 2004; Kullander et al., 2018). Its representatives cover a wide range of body sizes from small (though not very small) to some of the largest Neotropical cichlids and are predominantly and also ancestrally specialized and often among the top predators, especially in smaller sized rivers and streams. The smaller sized species feed mainly on bentic (but also terrestrial) invertebrates and small fishes, while the larger and large species are predators of fishes and large invertebrates (Stawikowski and Werner, 2004; Kullander et al., 2018).

Crenicichla species diversity is centered on the Amazon-Orinoco-Guiana (AOG) core area of the Neotropical region (Greater Amazonia) (Stawikowski and Werner, 2004), which is also the center of diversity for virtually all Neotropical fish groups (Albert and Reis, 2011; Van der Sleen and Albert, 2018). Most species groups of the genus co-occur in this core (Ploeg, 1991; Stawikowski and Werner, 2004; Piálek et al., 2012), but the most morphologically and ecologically distinct species and the only species that depart from their ancestral predatory ecomorphology are found in the southern subtropical region of the Neotropics, more specifically only in the La Plata river basin,

93 and here only in the Middle Paraná and its major affluent, the Iguazú river, and in the 
94 Uruguay river (Piálek et al., 2012; Burress et al., 2018a,b). These are the only 95 Crenicichla assemblages where we find specialized molluscivorous species, 96 specialized large-lipped invertebratofagous crevice feeders, and even partially

97 herbivorous species (periphyton grazers), together with both benthic as well as pelagic 98 invertebratophagous-piscivorous predators, and all or some of these ecomorphs occur 99 in sympatry in the Middle Paraná and the Uruguay river basins and have most probably 100 evolved in sympatry (Piálek et al., 2012, 2019a,b; Burress et al., 2018a,b).

Ploeg (1991) while quite outdated is still the main reviewer of Crenicichla systematics and the author of most of the informal species groups within the genus.

103 The species groups differ in many parameters including body size, head and body 104 proportions, coloration patterns as well as in ecological characteristics and preferred habitats, and for some groups in biogeography. Apart from Ploeg (1991) initial species

106 group divisions were also introduced by Kullander $(1991,1997)$ and the most 107 comprehensive review of all aspects of Crenicichla diversity is given by Stawikowski 108 and Werner (2004). The following species groups within the genus have thus been 109 proposed so far: Acutirostris, Lacustris, Lugubris, Macrophthalma, Missioneira, 110 Reticulata, Saxatilis, Scottii, and Wallacii. Based on presently valid numbers of species 111 the largest species groups are Saxatilis and Lacustris, both with 25 species. The 112 distributions of the Acutirostris, Lugubris, Macrophthalma, Reticulata, Saxatilis, and

113 Wallacii groups are centered on the AOG core of South America where they all overlap 114 in their distributions but generally prefering different habitats, while the Lacustris, 115 Missioneira, and Scottii groups are endemic to SE South America (chiefly the SE 116 Atlantic coast, the La Plata river basin and the northern Pampean region of Argentina) 117 outside of the AOG core. The Lacustris and Missioneira groups include the sympatric 118 species flocks of highly ecomorphologically distinct species (Piálek et al., 2012, 119 2019a,b; Burress et al., 2018a,b), while the AOG core centered species groups are 120 internally much more ecomorphologically homogeneous.

121 The type species of the genus is Crenicichla macrophthalma Heckel, 1840, the 122 sole representant of the Marcrophthalma species group, a morphologically rather 123 recognizable species with large eyes. Crenicichla contains two genus-level names 
124 currently considered as synonyms, Batrachops Heckel, 1840 (Kullander, 1986) and 125 Boggiania Perugia, 1897 (Kullander, 1986).

126 Crenicichla currently includes 132 nominal species, of which 96 are generally 127 considered valid and 36 as synonyms (www.cichlidae.com), but this division has 128 differed between authors quite widely (Ploeg, 1991; Stawikowski and Werner, 2004; 129 Kullander et al., 2018). Crenicichla is thus currently the largest Neotropical cichlid 130 genus, followed by Apistogramma (with 106 nominal species, 93 of which are generally 131 considered valid and 13 synonyms; www.cichlidae.com). A list of valid species of

132 Crenicichla with complete species names including author (plus a division of the valid 133 species into the species groups), plus nominal species presently considered as 134 synonyms are given in alphabetical list in Appendix 1, and by year of description in Appendix 2.

136 The real species diversity in Crenicichla is however based on preliminary and 137 predominantly upublished information (pers. obs.) or information published only in 138 cichlid hobby literature (Stawikowski and Werner, 2004) quite probably significantly 139 underestimated. At least 85 putative undersribed species have been proposed in the 140 literature (summary in Stawikowski and Werner, 2004) (Appendix 3). The large number 141 of proposed putatively undescribed species in the genus have predominantly been 142 identified thanks to the collecting efforts of the cichlid hobbyists. Stawikowski and 143 Werner (2004) is the main review of systematics, literature and species diversity, 144 provides the characterization and photographs of the majority of the nominal as well as 145 the putative undescribed species, including their proposed classification into species 146 groups.

In 1988 Kullander described a new cichlid genus Teleocichla Kullander, 1988 with then six species of small elongated cichlids, the only cichlids in the Neotropics 150 morphologically similar to Crenicichla (Kullander, 1988). The type species of that genus 151 is Teleocichla centrarchus Kullander, 1988 and the genus presently contains nine 152 species (Appendices 1-3) all endemic to the Eastern Amazon within the AOG core of 153 the Neotropics. Teleocichla species are superficially most similar to the Wallacii group 154 of Crenicichla, mostly due to their similarly small size, but are distinct from the Wallacii 
155 group and from all Crenicichla in many morphological characters, especially in the very 156 distinct morphology of the head (especially a short, downturned snout and short jaws 157 with upper slightly projecting in front of lower vs. the contrary) and also body (reduced 158 swim bladder, lateral lines and pelvic-fin shape) with obvious specializations for a 159 benthic and rheophilic mode of life in rapids (Kullander 1988; Ploeg, 1991). Parallel but 160 distinct adaptions for a similar lifestyle are also found in some sympatric members of 161 the Lugubris group of Crenicichla, which are however large piscivorous species unlike 162 the small benthic-invertivorous Teleocichla species (Kullander 1988; Ploeg, 1991; 163 Stawikowski and Werner, 2004).

$164 \quad K u l l a n d e r(1988)$ hypothesized Teleocichla to be closely related to Crenicichla 165 (they are the only similar groups of cichlids in the Neotropics) but unequivocal 166 synapomorphies are few (Kullander, 1988; Ploeg, 1991). The close relationship of 167 these genera is straightforward, but a more intriguing question is whether Teleocichla is 168 a separate genus from Crenicichla, especially given the large diversity within the latter. 169 Kullander (1988) gave many characters that are different in the two genera, but they 170 are either correlated with habitat (benthic and rheophilic in Teleocichla vs. extremely 171 wide ranging in Crenicichla), variable, or unconvincing and not evidently 172 synapomorphic for either genus (Kullander, 1988; Ploeg, 1991). Ever since the 173 description of Teleocichla its separate generic status has thus been questioned 174 (summary in Stawikowski and Werner, 2004) and Ploeg (1991) in the so far only formal 175 review even synonymized Teleocichla with Crenicichla. The reasons for the lack of 176 general acceptance of Teleocichla were its not completely convincing diagnosis, that it 177 has not been included in the morphological phylogeny of Kullander (1998) or any 178 subsequent morphological phylogeny, and molecular phylogenies, which are actually 179 strongly sugesting that Teleocichla is one of the species groups of Crenicichla (Piálek 180 et al., 2012; Ilves et al., 2018; Burress et al., 2018a, the so far most thorough study with 181 the most included species and the largest genetic dataset for both genera).

This study is designed as a first major step in a series of contributions that will 184 review the species diversity of Crenicichla (including Teleocichla) because as outlined 185 above it is 1) the largest Neotropical cichlid genus, 2) with the largest number of 
186 proposed putatively undescribed species and 3) because it is an important component

187 of South American fish communities, where it plays an important ecological role and 188 has the potential to become a useful biogeographic and ecological bioindicator (due to 189 its high endemism and narrow habitat preferences). A good knowledge of the species 190 diversity of the genus is thus of key importance.

191 In this study we have assembled a mtDNA (ND2 and cytb) dataset of 681

192 ingroup specimens representing 77 out of 105 presently recognized valid species and 19310 out of 36 nominal species treated as synonyms (Appendices 1 and 2) plus over 50 194 of the at least 85 postulated putative species (Appendix 3). With the use of 195 phylogenetic analyses of this dataset including a dated one and together with three 196 molecular species delimitation methods we test the species diversity hypothesis within 197 the genus (i.e. valid species, synonymized species and postulated putative species)

198 that has been established based on traditional characters. This same specimen 199 sampling with future additions will be in the consecutive studies used for a nuclear DNA 200 phylogeny reconstruction (ddRAD and whole genome) to compare with the here 201 presented results based on mtDNA and for morphological analyses and revisions.

\section{Materials \& Methods}

\section{Specimen sampling}

This study is based on a total of 681 Crenicichla individuals (including Teleocichla) (Appendix 1, Table S1) that were collected throughout the whole distribution of the two genera in South America (Fig. 1) from 129 locations (La Plata 28, E. coast 10, W. Amazon 17, Orinoco 19, Negro 6, E. Guiana shield 24, E. Amazon 25) in 31 major river drainages (=ecoregions sensu Abell et al., 2008; La Plata 7, E. coast 6, W. Amazon 3, Orinoco 5, Negro 1, E. Guiana shield 3, E. Amazon 6).

211 Tissue samples for DNA analysis were taken from the right pelvic fin, stored in

212 95\% ethanol and deposited in the tissue collection of the Department of Zoology,

213 Faculty of Science, University of South Bohemia. Voucher specimens were 214 photographed alive, permanently tagged and identified using a unique code (C1 to 215 C704; Table S1), and following euthanasia (overdose of anaesthetic MS-222 Tricaine 216 methanesulfonate and Benzocaine hydrochloride dissolved in water) preserved in $10 \%$ 
217 formalin and later transferred to $70 \%$ ethanol. Voucher specimens are deposited in the

218 fish collection of the Department of Zoology, Faculty of Science, University of South

219 Bohemia, and in the fish collections of Museo de La Plata (MLP), Museo Argentino de

220 Ciencias Naturales (MACN), and Asociación Ictiológica La Plata (Al). Study of the

221 animals was approved by the Control Commission for Ethical Treatment of Animals,

222 University of South Bohemia, Faculty of Science, Czech Republic (17864/2005-30/300).

223

224

Specimens for the study were obtained by extensive collecting lasting several decades through our collecting and a network of dedicated cichlid hobbyists, cichlid fish importers, and colleagues who have collected and kept animals over this period. Our collecting was done under permanent collection permits to Hernán Ortega (National University of San Marcos, Lima, Peru), Javier A. Maldonado Ocampo (Pontificia Universidad Javeriana, Bogotá, Colombia), Cecilia Rodríguez-Haro (Universidad Regional Amazónica IKIAM, Tena, Ecuador), and Nadacion FUDECI (Venezuela) under bilateral agreements, and under temporary permits from the Administración de

232 Parques Nacionales and Ministerio de Ecología y Recursos Naturales Renovables,

233 Argentina (permits nos. NEA328 rnv3 and Res: 509/07, respectively). Specimens from

234 Brazil and the Guianas were collected and imported by a consortium of professional 235 aquarium fish importers coordinated by JG (Amazon Peixes Ornamentais LTDA, Brazil;

236 Netuno Aquarium Peixes Orn LTDA, Brazil; Amazonstar Comercio de Peixes 237 Ornamentais LTDA, Brazil; FLOCAMBUS S.A.R.L, French Guiana; Oleeja Ornamental 238 Fish Export, Suriname; and Panta Rhei GmbH, Hannover, Germany) (permits nos. 239 0121/UVAGRO/AERO/16, 0545/UVAGRO/AERO/15, 00101/SVA-AIRJ/LPS L, 240 05021/SVAGRU/10, 0229 UVAGRO-ABEL 15, 0938 UVAGRO-AEROBEL 14, 0462 241 UVAGRO-AEROBEL 15, 0069 UVAGRO-AEROBEL 20, 011013/2016/SVAGRU, 242 004989/2020/VIGIAGRO, 00006331/2020-SVA-GRU, 1351 SVA-GRU 13, 243 2012403102A, and 201804004E). The imported specimens are kept alive and are 244 being reared in care of JG, in a network of fish hobbyists coordinated by JG and 245 voucher specimens are kept at the fish collection of the Department of Zoology, Faculty 246 of Science, University of South Bohemia. Collection localities are given in Table S1 and 247 are visualized in Fig. 1. 
Species determination

250 We combine morphological species determination with post-hoc species delimitation

251 using molecular mtDNA cytochrome b (cytb) and ND2 markers following the protocol of

252 Říčan et al. (2019). Specimens were identified to species with the use of original 253 descriptions, identification keys, and comparative material. Specimens that are new 254 undescribed species or that could not be identified to species level are reported as 255 "Crenicichla sp." (possibly new/unidentified species), specimens that were identified to 256 species only with reservation are reported as "Crenicichla cf. species" (a species that 257 conforms to diagnosis with reservation and occurs outside its supposed distribution, 258 possibly new) or "Crenicichla aff. species" (closely related species, revealed by DNA 259 phylogeny, possibly new). For summary statistics, "C. aff. species" and "C. cf. species" 260 are considered equivalent to "C. species".

Molecular markers

263 For molecular phylogenetic analyses and delimitation of putative species we have used two mitochondrial (mtDNA) markers, the cytochrome $b$ (cytb) gene and the ND2 gene following the protocol of Ríčan et al. (2019). The cytb is the single most often used molecular marker in cichlid phylogenetic studies and has been one of the first molecular markers to provide well resolved phylogenies of the Neotropical cichlids that have subsequently been virtually completely confirmed by later studies including recent phylogenomic studies (e.g. Říčan et al., 2016; Ilves et al., 2018; Burress et al., 2018a,b). The ND2 gene has been found to have in Crenicichla even better and more evenly distributed support values across both shallow and deep nodes in the phylogeny

272 than the cytb (Piálek et al., 2012).

273

\section{Laboratory methods}

275 Genomic DNA was extracted from ethanol-preserved fin tissue using the JETQUICK 276 Tissue DNA Spin Kit (Genomed, Germany) following standard protocol and as 277 described in Říčan et al. (2019). The primers and reaction conditions of polymerase 278 chain reaction (PCR) amplification are as in Říčan et al. (2008). The products were 
279 analyzed in an ABI 3730XL automated sequencer (Applied Biosystems; Macrogen Inc.,

280 Korea). Contiguous sequences of the gene segments were created by assembling 281 DNA strands (forward and reverse) using GENEIOUS v. 11.0.2 (http://geneious.com, 282 Kearse et al., 2012). Nucleotide coding sequences were also translated into protein 283 sequences to check for possible stop codons or other ambiguities. All newly generated 284 sequences (558) were deposited in GenBank under Accession numbers MW554711285 MW584412 (Table S1). Sequences were aligned using MUSCLE v. 3.8 (Edgar, 2004), 286 using the default settings.

287

288

Phylogenetic methods

As outgroups we have included Astronotus ocellatus and Satanoperca jurupari based on previous knowledge of cichlid relationships and studies dedicated to CrenicichlaTeleocichla and its most closely related groups (Piálek et al., 2012; Ilves et al., 2018; Burress et al., 2018a). Maximum parsimony (MP) analysis in PAUP* 4b.10 (Swofford, 2003), maximum likelihood (ML) analyses in RAxML v8.2.4 (Stamatakis, 2014) and Bayesian inference analyses (BI) in MrBayes v3.1.2 (Huelsenbeck \& Ronquist, 2001; Ronquist \& Huelsenbeck, 2003) and BEAST v1.8.4 (Drummond \& Rambaut, 2007) were used for phylogenetic inference following the protocol of Ríčan et al. (2019). The MP phylogenetic analyses in PAUP* were run with 500 random sequence additions, 10 trees kept per addition, and a hs (heuristic) search on the saved trees to find all the shortest trees. Bootstrap analyses were done using the same approach, with 5 random sequence additions per one replication. Bootstrap analyses were run with 1000 replications. The $\mathrm{BI}$ analyses in MrBayes (and BEAST, see below) were run with partitioning into codon positions (1st+2nd vs. 3rd). An optimal model of evolution according to Akaike criterion was selected using MrModeltest 2.2 (Nylander, 2004) and

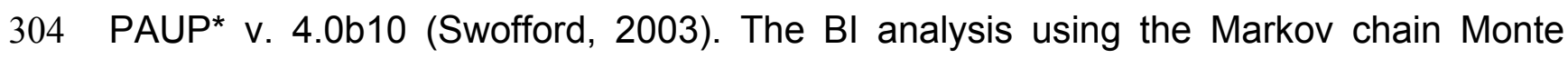
Carlo (MCMC) simulation was run for 2 million generations with trees sampled and saved every 1000 generations. Two independent analyses, each comprising two runs with eight chains, were performed to compare results of independent analyses. The analyses were run at the freely available Cipres server (https://www.phylo.org/) and in the Czech academic National Grid Infrastructure MetaCentrum (www.metacentrum.cz). 
310 The first $10 \%$ of trees from each run were discarded as burn-in. Convergence of the

311 runs was estimated with the use of graphical visualization and diagnostics (especially

312 the effective sample size; ESS) in Tracer v. 1.8.4 (Rambaut et al., 2018). The

313 remaining trees were used for reconstruction of the $50 \%$ majority-rule consensus tree

314 with posterior probability (PP) values of the branches.

315

316 Molecular clock dating analyses in BEAST

317 For divergence time estimation we used the Bayesian Evolutionary Analysis by

318 Sampling Trees (BEAST) software package version v.1.8.4 (Drummond \& Rambaut,

319 2007) with parameters as in MrBayes analyses (except for 30 million generations). We

320 used the relaxed molecular clock model with lognormal distribution of rates and for tree

321 prior the coalescent model with constant size. The calibration of the molecular clock

322 was performed using secondary calibration from the study of Musilová et al. (2015)

323 which was focused on the dating of Neotropical cichlids. Musilová et al. (2015)

324 employed a calibration using a set of Neotropical fossil cichlid species and the study is

325 so far the best sampled dated phylogeny of the Neotropical cichlids. For the calibration

326 of Crenicichla we have used the basal node of the genus, estimated by Musilová et al.

327 (2015) at $28 \mathrm{Ma}$ (normal distribution; SD=1).

328 The analyses were run at the freely available Cipres server (https://www.phylo.org/).

329 Runs were checked for convergence with Tracer v.1.8.4 (Rambaut et al., 2018). Four

330 well converged runs were combined in LogCombiner v.1.8.4 with a burnin of $10 \%$ for

331 each of the data partition schemes. The final tree for each data partition scheme was

332 produced from these data with TreeAnnotator v.1.8.4.

333

334 Species delimitation analyses using GMYC and PTP

335 We employed the General Mixed Yule Coalescent (GMYC) and Poisson tree processes

336 (PTP) analyses for molecular species delimitation using the studied markers and

337 following the protocol of Ríčan et al. (2019). Both methods were designed for delimiting

338 species based primarily on single molecular markers (hence where multilocus

339 coalescent-based methods are not applicable). 
340 The General Mixed Yule Coalescent (GMYC) model (Pons et al., 2006; Fujisawa 341 and Barraclough, 2013) is frequently used in empirical studies (Fontaneto et al., 2007;

342 Monaghan et al., 2009; Carstens and Dewey, 2010; Vuataz et al., 2011; Powell, 2012)

343 and the newer Poisson tree processes (PTP) model (Zhang et al., 2013) has been 344 shown to even outperform the GYMC method where distances between species are 345 small. Both methods outperform OTU-picking methods (relying on simple sequence 346 similarity thresholds) and are more robust to cases where the barcoding gap is absent 347 (Zhang et al., 2013). Both methods model speciation (among-species branching events) 348 via a pure birth process and within-species branching-events as neutral coalescent 349 processes. The methods identify the transition points between inter- and intra-species 350 branching rates by maximizing the likelihood score of the model. While the GMYC 351 method uses time to identify branching rate transition points (hence only on a time352 calibrated ultrametric tree) the PTP method directly uses the number of substitutions 353 and does not require a time-calibrated ultrametric tree. Both methods assume that all 354 lineages leading from the root to the transition points are different species.

355 PTP and GMYC analyses were run at the freely available web interface 356 (http://species.h-its.org and https://mptp.h-its.org). Prior to analyses a haplotype 357 dataset was created in Fabox (Villesen, 2007). The mPTP and bPTP analyses were 358 run on the MrBayes haplotype tree and the GMYC analysis on the ultrametric 359 haplotype BEAST tree.

360

361 Results

362 This study is based on the by far largest sampling of Crenicichla specimens (including 363 Teleocichla) and species. The aligned mtDNA matrix comprised 681 specimens plus 364 outgroups with 2163 aligned base pairs of the concatenated cytb and ND2 markers. 365 The ingroup dataset comprised a total of 591 unique haplotypes. Phylogenetic 366 hypotheses generated from this dataset using MP, ML, and $\mathrm{BI}$ analyses are highly 367 congruent and the majority of the nodes within species groups and at the level of 368 species (the focus of this study) are well supported (PP>95\%, BS>75\%; cf. Fig. 2 and 369 Figs S1 and S2) except for parts of the Missioneira and Saxatilis groups as detailed 
370 below. The dated BI BEAST topology (Figs 2-6) is used throughout the text to describe 371 and discuss results unless otherwise noted.

372 Teleocichla is in the mtDNA BI BEAST phylogeny the sister-group of the genus

373 Crenicichla, while in RAXML phylogeny it is nested within Crenicichla, but above two of 374 the unsupported nodes. The following supragroup relationships are the same in the BI 375 BEAST (Fig. 2-6) and RAXML (Fig. S1-S2) phylogenies. One clade includes the 376 Missioneira group plus Lacustris (the Scottii group is firmly nested within the latter; Figs 3772 and 3-6), followed by the Macrophthalma, followed by the Reticulata. The remaining 378 species groups form a second clade in the BEAST analysis (Fig. 2) where the Saxatilis 379 is the sister group to the Acutirostris, followed by the Lugubris, followed by the Wallacii 380 (Figs 2 and 3-6). In the RAXML analysis (Fig. S1, S2) the Saxatilis is the sister group to 381 the Lugubris, followed by the Acutirostris, and the Wallacii is the sister group to the 382 remaining groups including Teleocichla. The conflicting supragroup positions between 383 the BEAST and RAXML analyses are without statistical support in either of the 384 analyses.

385 Description of the detailed species-level relationships is beyond the scope of the 386 present paper but are well depicted in Figs 3-6, in Table S1, and the overal species387 level diversity patterns are described in a concise form below and in more detail in the 388 Discussion. The overal estimated number of species derived from delimitation analyses 389 ranged from 126 putative species (mPTP), through 153 (GMYC) to 168 (bPTP) (Table 390 S1; Figs 2-6). The total number of species delimited in Crenicichla (including 391 Teleocichla) in this study is thus at least twice as high (126-168) as the number of 392 included valid species (77).

393 The presently recognized valid species are mostly found well supported in our 394 analyses. Of the 77 included valid species our analyses supported all but several 395 weakly diagnosed species in the Saxatilis group (C. proteus/C. lucius, C. inpa/C. alta, C. 396 nickeriensis, C. menezesi, C. coppenamensis, C. albopunctata), and then the rapidly 397 diverged but morphologically distinct species of the Missioneira group (C. missioneira, 398 C. minuano, C. tendybaguassu, C. hadrostigma, C. celidochilus) which are not found 399 monophyletic even under our dense sampling. Of the 77 included valid species all three 400 delimitation analyses supported 62 species, and at least two supported 64 species. 
All 10 (out of 36 ) included taxa presently treated as synonyms are also all

402

403

404

405

406

407

408

409

410

411

412

413

414

415

416

417

418

419

420

421

422

423

424

425

426

427

428

429

430

431 Discussion

supported by most analyses as distinct from the species with which they are currently synonymized (shown in orange in Figs 3-6; Appendices 1-3, Table S1; Crenicichla biocellata von Ihering, 1914; Crenicichla cardiostigma Ploeg, 1991; Crenicichla dorsocellata Haseman, 1911; Crenicichla elegans Steindachner, 1881; Crenicichla guentheri Ploeg, 1991; Crenicichla menezesi Ploeg, 1991; Crenicichla obtusirostris Günther, 1862; Crenicichla punctulata (Regan, 1905); Crenicichla rutilans (Jardine, 1843). Crenicichla edithae Ploeg, 1991 (Middle Rio Paraná) is currently treated as a synonym of $C$. lepidota (Rio Guaporé). We have not been able to include material from the type locality of C. lepidota, but other southern Amazonian cf. lepidota (Xingu, Tapajos, Teles Pires, Guapimirim) are distinct from C. edithae in our analyses and C. edithae additionally has moderate geographic structuring.

The described species based on our analyses form only half of the delimited species diversity in Crenicichla. The second half of the delimited Crenicichla species diversity is to a large extent formed by species that have been postulated as separate species in the cichlid hobby literature but have never been formally described. There are few of these species among the southern groups of Crenicichla (Missioneira group, Lacustris group) which have recently been revised (see Introduction), but they are prevalent among the Amazonian Crenicichla groups and in the Lugubris, Saxatilis and also Wallacii groups they actually form the majority of the delimited species diversity (shown in violet in Fig 3-6; delimited species 31-41, 32-51, 9-12 vs. included valid species $12,19,4$, respectivelly). The most conservative estimate of these species is 40 , given in the mPTP delimitation, while the GMYC and bPTP delimit 46 of them in common.

Finally, the remaining portion of the delimited putative species are those without any previous reference. These total a minimum of 18 delimited putative species in the mPTP analysis while 37 are the shared minimum between the GMYC and bPTP delimitations, and most analyses agree on 25 of these putative species, most of them again in the Lugubris group.

Peer] reviewing PDF | (2021:01:57123:2:0:NEW 26 Aug 2021) 


\section{Phylogenetic relationships}

433 Prior to this study the phylogenies with the most representative sampling of 434 Crenicichla and Teleocichla were the studies of Piálek et al. (2012) and Burress et al. 435 (2018a). Piálek et al. (2012) included 161 specimens and 35 species in a multilocus 436 mtDNA+nDNA phylogeny, while Burress et al. (2018a) included 57 species in a 437 reduced genome representation nDNA ddRAD phylogeny. At the species level the 438 relationships in Piálek et al. (2012) and Burress et al. (2018a), derived from different 439 molecular markers, are highly congruent and are also highly congruent with our present 440 study with a much denser sampling, the only exceptions are within the Missioneira 441 group and parts of the Saxatilis group which lack statistical robustness of resolution in 442 all three studies.

443 At the level of the species groups Teleocichla is in both Piálek et al. (2012) and 444 Burress et al. (2018a) nested within Crenicichla as the sister group of the Wallacii, 445 Saxatilis and Lugubris groups, in Burress et al. (2018a) with all analyses of the ddRAD 446 data using various settings, parameters and matrix sizes giving a 100\% bootstrap 447 support for this phylogenetis position. In our mtDNA phylogeny in this study the position 448 of Teleocichla is equivocal, either nested within Crenicichla (MP and ML analysis; Figs 449 S1-S2), or as a sister group of Crenicichla (BI analysis; Figs. 2-3), in both cases without 450 statistical support. The uncertainty of Teleocichla position in mitochondrial markers is

451 likely due to saturation at this large phylogenetic distance (see Piálek et al., 2012 for 452 details). Based on available studies (Piálek et al., 2012; Burress et al., 2018a; this 453 study) Teleocichla is thus most probably a species group within Crenicichla, the sister 454 group of the Wallacii, Saxatilis and Lugubris groups (including Acutirostris group) 455 (Burress et al., 2018a).

456 The southern groups of Crenicichla (Missioneira, Lacustris, Scottii) form a well 457 supported monophyletic clade in our mtDNA analyses (Figs 2, 5-6 and S1-S2) as well 458 as in other studies of Crenicichla (Piálek et al., 2012; Burress et al., 2018a) with the 459 Missioneira being the sister group of the Lacustris. The Scottii group is found strongly 460 nested within the Lacustris group as it is in Piálek et al. (2012) and Burress et al. 461 (2018a). 
The sucessive sister groups of this southern clade are the Macrophthalma group

463

464

465

466

467

468

469

470

471

472

473

474

475

476

477

478

479

480

481

482

483

484

485

486

487

488

489

490

491

492

and the Reticulata group, both relationships being well supported in our mtDNA analyses (Figs 2, 4-6 and S1-S2) as they are in the mtDNA+nDNA multilocus study of Piálek et al. (2012), while in the nDNA ddRAD study of Burress et al. (2018a), the Reticulata group is the sister group of the southern clade followed by the Macrophthalma group (bootstrap supports for this alternative relationship have values of $60,79,86,88$ and $99 \%$ in the various analyses of the ddRAD data in Burress et al., 2018a).

The remaining species groups (Wallacii, Saxatilis, Lugubris and Acutirostris) form the second main clade of Crenicichla in the phylogenetic BEAST analysis of our mtDNA data (Fig. 2-4), and with the exclusion of the Wallacii group also in the RAXML analysis (Fig. S1-S2). The relationships between the Saxatilis, Lugubris and Acutirostris groups however differ between the BEAST and RAXML analyses and lack statistical support. Both Piálek et al. (2012) and Burress et al. (2018a) found Lugubris and Acutirostris as the sister group of Saxatilis followed by Wallacii, which is a different relationship from both our mtDNA phylogenies with lack of statistical support at these nodes (Figs 2-4 and S1-S2), while the topology in both Piálek et al. (2012) and Burress et al. (2018a) is strongly supported.

The Acutirostris group (and the Scottii group; see above) is the only species group whose species composition and monophyly is questioned by molecular phylogenetic analyses. In our mtDNA analyses the Acutirostris group appears as a separate clade but without statistical support that includes $C$. acutirostris, $C$. multispinosa, C. ternetzi and also C. cincta (Figs 2-4, S1-S2). In the nDNA ddRAD phylogeny of Burress et al. (2018a) the group is not monophyletic but is paraphyletic to the Lugubris group ( $C$. acutirostris at the base followed by $C$. multispinosa followed by C. cincta) with strong statistical support and hence probably best subsumed into the latter group, as has been proposed in Stawikowski and Werner (2004), where it is treated as a species complex within the Lugubris group.

In summary our analyses together with previous molecular studies of Crenicichla support the monophyly of the Lacustris, Lugubris, Macrophthalma, Missioneira, Reticulata, Saxatilis, and Wallacii species groups which form two main clades of 
493 Crenicichla, the Lacustris-Missioneira-Reticulata-Macrophthalma clade, and the

494 Lugubris-Saxatilis-Wallacii clade, and we subsume the Acutirostris group into the

495 Lugubris group and the Scottii group into the Lacustris group.

496

497

\section{Species diversity}

498 Our results clearly demonstrate that the species diversity in Crenicichla is 499 significantly underestimated. While our study included 77 valid species our analyses 500 delimited between 126 and 168 species (Fig 3-6), at least twice as many. Extrapolation 501 from the ratio of total valid species (105) and the number of valid species included in 502 our study (77) (105/77) and the here delimited species (126-168) suggests the 503 minimum number of species in Crenicichla to be 172-229 (Figs 3-6).

504 While the profesional ichthyological knowledge of the species diversity in the 505 group is very limited as seen from our results, the cichlid-hobby knowledge of the 506 Crenicichla fauna is actually much better. This is evident from the correspondence 507 between the here delimited species and the potentially undescribed species identified 508 in the cichlid hobby literature. The cichlid hobby literature identifies at least 85 509 potentially undescribed species of Crenicichla and Teleocichla (Appendix 3) and 510 essentially all of those that were included in the present study (50) have been delimited 511 by the molecular analyses (40-46 depending on the delimitation method; Figs 3-6; this 512 group of delimited taxa shown in violet). Adding the at least 85 identified potentially 513 undescribed species to the presently valid species (105) still gives an underestimated 514 total of 190 Crenicichla plus Teleocichla species compared to our extrapolation based 515 on molecular species delimitation which is in the range of $172-229$ species. Virtually all 516 of these species unrecognized by the professional literature are found in the Amazon517 Orinoco-Guiana core of South American fish diversity (Albert and Reis, 2011; Van der 518 Sleen and Albert, 2018), where they in the C. lugubris and C. saxatilis groups actually 519 form the majority of the delimited species diversity (Figs 3-6; delimited species 31-41, $52032-51$ vs. included valid species 12,19 , respectivelly). Many of the delimited species in 521 this category are presently subsumed under described species and especially under 522 those with putatively large distribution areas. Our mtDNA phylogeny and species 523 delimitations together with their various degrees of morphological distinctiveness 
524 clearly demonstate that these putatively widely distributed species are an 525 oversimplification that does not reflect true diversity.

526 In the following paragraphs we provide a short review of the putative new 527 species previously proposed in the cichlid-hobby literature and here for the first time 528 delimited and supported in molecular analyses. We provide this review by species 529 groups, starting with the $C$. lugubris and $C$. saxatilis groups, where this hidden diversity 530 actually forms the majority of the species diversity.

531

532

533

534

535

536

537

538

539

540

541

542

543

544

545

546

547

548

549

550

551

552

553

Lugubris group

In the Lugubris group the species $C$. lugubris and $C$. johanna have in the present ichthyological definition very large distribution areas covering virtually the whole of the Amazon/Orinoco/Guiana core. Our analyses demonstrate that these and most other widespread species are an illusion and that they are actually species complexes composed of allopatric/parapatric species that have in most instances been separated for millions of years (Fig. 3). The type of C. lugubris is from the Negro/Guianas area, in our analyses clearly delimited as a separate species, and our analyses further confirm the proposed allopatric species $C$. cf. lugubris Orinoco (here actually as three delimited species $C$. cf. lugubris Caroní, C. cf. lugubris red, C. cf. lugubris Caura), C. cf. lugubris Atabapo-Ventuari, all from the Orinoco basin, and C. cf. lugubris Amazon, C. cf. Iugubris Tocantins, C. cf. Iugubris Tapajos I, and C. cf. lugubris Tapajos II, all from the Amazon basin. The divergence within the presently recognized C. lugubris sensu lato ranges from 0.6 to $7.9 \mathrm{My}$ with a mean of $3.5 \mathrm{My}$ based on our calibration (Fig. 3) demonstrating long isolation between the allopatric species sensu stricto. The $C$. lugubris group additionally includes several very clearly distinct species that have been known for a long time and that still await description. All that were included in the present study are delimited by our molecular analyses. These are C. sp. Atabapo, C. sp. Xingu I, C. sp. Xingu II (also known as C. cf. lugubris Xingu), and C. sp. Xingu III (recently described as $C$. dandara Varella \& Ito, 2018). Apart from the here sampled proposed allopatric species from within the $C$. lugubris complex our analyses do not include C. cf. lugubris Uaupés and C. sp. Uaupés (recently described as C. monicae 
554 Kullander \& Varella, 2015), which both represent clearly distinct morphologically555 diagnosed species.

556 The type of $C$. johanna is from the western Amazon, more precisely from the Rio 557 Guaporé, and while we were not able to sample C. johanna from this particular river 558 basin, our analyses clearly delimited other western Amazonian samples as a distinct 559 species. Our analyses further confirm the proposed allopatric species $C$. cf. johanna

560 Orinoco I, C. cf. johanna Orinoco II, C. cf. johanna Amazonian Guiana, and C. cf. 561 johanna Eastern Amazon. We have not sampled $C$. johanna from several other large 562 tributaries that probably also represent distinct allopatric species (Tapajós, Xingu, 563 Tocantins, Guianas, Negro, Branco, Aripuanã-Roosevelt, etc). The divergence within 564 the here analyzed C. johanna sensu lato ranges from 1.2 to 6.7 My with a mean of 3.5 565 My based on our calibration (Fig. 3) demonstrating long isolation between the allopatric 566 species sensu stricto.

Several other species within the C. lugubris group have rather large distribution 568 areas (e.g. C. cincta, C. lenticulata, C. marmorata, C. strigata) but most of them we 569 have only been able to sample from single river basins. For $C$. lenticulata our analyses do find hidden diversity with the type of $C$. lenticulata from the Rio Negro in our analyses clearly delimited as a separate species from $C$. cf. lenticulata Orinoco. The divergence within the presently recognized $\mathrm{C}$. lenticulata sensu lato is 1.0 to $1.8 \mathrm{My}$ based on our calibration (Fig. 3). On the other hand in C. marmorata which we have sampled from several different basins (e.g. Xingu, Arapiuns, Curuá) our delimitation analyses do not converge on the same number of species, but the low genetic distances only appear to suggest the presence of a single species.

Saxatilis group

The Saxatilis group is the most complicated group both in traditional systematics and in our results of molecular phylogeny and species delimitation. The reasons are strong morphological similarity of the species and short internodes between some of

582 the species (Figs 4 and S2). The Crenicichla saxatilis group contains a large number of 583 generally weakly diagnosed species and most of the unresolved or unsupported 584 nominal species of Crenicichla in our analysis are found in this species group (and in 
585 the even younger C. missioneira complex of the C. lacustris group). Despite the limited 586 morphological variability and the young age of some of the species our delimitation 587 analyses delimit the largest number of species of all Crenicicichla groups in this 588 species group (32-51 species). The group is thus very complicated yet clearly contains 589 a large diversity of species. Most of the nominal species have distributions in the 590 Guianas and fall into the informally called saxatilis complex, as opposed to the second 591 main complex, the lepidota complex, whose nominotypical species are from southern 592 tropical South America. Both complexes are only weakly defined and overlap 593 throughout Amazonia, but our mtDNA phylogeny largely separates them as two 594 monophyletic groups. There are additionally largely endemic complexes in the western 595 Amazon and in the Orinoco basin which appear in basal positions of the whole group 596 and of the two main complexes in our mtDNA phylogeny.

Within the smaller Orinocoan complex our analyses delimit all the proposed 598 Inirida species (C. sp. Inirida I, C. sp. Inirida II, C. sp. Inirida III), C. sp. Caura and C. cf. alta as distinct and distantly related to $C$. alta (nominotypical from Guyana; in our sampling from Venezuelan tributaries of Guyana).

Within the western Amazonian complex our analyses delimit multiple species within the nominal C. anthurus (C. lucius ?, C. proteus ?) and C. semicincta (and C. cf. semicincta), but the species boundaries between these nominotypical species require inclusion of topotypical samples and of denser area sampling given the wide putative distribution of these species throughout the western Amazon.

Within the large lepidota complex our analyses delimit many species in this complex with a high degree of endemism. The terminal clade of the complex is made of three clades of $C$. edithae, two in the Middle Paraná (one also including Pantanal) and a separate clade of $C$. aff. edithae Iguazú. The sister-group of this clade is composed

610 of many delimited regional endemics from the south of the eastern Amazon (C. ploegi, 611 C. isbrueckeri, C. cf. lepidota Teles Pires, C. cf. lepidota Juruena, C. cf. lepidota Xingu) 612 and Upper Paraná (C. britskii), followed by C. cf. lepidota Guapimirim from the coast.

613 The large saxatilis complex has most of its named species in the Guianas and 614 the eastern Amazon but our analyses fail to delimit many of the named species (C. 615 albopunctata, C. coppenamensis, C. brasiliensis, C. nickeriensis, C. inpa due to low 
616 divergences and lack of reciprocal monophyly. On the other hand our GMYC and bPTP

617 analyses delimit a large number of separate species in the south of the eastern

618 Amazon and its tributaries (in French Guiana, Xingu, Tapajos, Tocantins), but the

619 mPTP analysis delimits them as a single unit (shown as $C$. aff. saxatilis or $C$. aff. inpa 620 in Fig. 4).

621

622

623

Wallacii group

624

In the Wallacii group our analyses find hidden diversity in the nominal species $C$.

625 ichthyological definition a large distribution area in the eastern Amazon. The type of $C$.

626 regani is from the Rio Trombetas (i.e. Amazonian Guiana) and is in our analyses

627 clearly delimited as a separate species (actually two in GMYC and pPTP analyses; Fig.

628 3) distinct from the allopatric populations of C. cf. regani Amazon and C. cf. regani

629 Tocantins. The nominal C. regani occurs throughout all of eastern Amazon in many of

630 its tributaries and based on color patterns probably represents several allopatric

631 species. One of the forms found in the Xingu treated previously provisionally as either

632 C. cf. regani Xingu or C. cf. urosema Xingu was recently described as $C$. anamiri Ito \&

633 Py-Daniel, 2015, but was not sampled in our analyses. The divergence within the here

634 analyzed $C$. regani sensu lato ranges from 0.8 to $4.2 \mathrm{My}$ with $C$. wallacii nested within

635 with a 3.2 Ma divergence based on our calibration (Fig. 3) demonstrating long isolation

636 between the allopatric species sensu stricto. The type of $C$. notophthalmus is from the

637 Rio Negro by Manaus and is in our analyses clearly delimited as a distinct species.

638 Undescribed populations from the Orinoco basin, referred to as either $C$. cf.

639 notophthalmus or C. sp. Orinoco in the cichlid hobby literature are in our analyses

640 composed of highly divergent clades, distinct from the nominal C. notophthalmus and

641 delimited as at least three distinct allopatric species C. cf. notophthalmus Orinoco I

642 (Ventuari), C. cf. notophthalmus Orinoco II (Inirida/Colombia), and C. cf. notophthalmus

643 Caroní. The divergence between the nominotypical C. notophthalmus and C. cf.

644 notophthalmus in the Orinoco basin is fully $10.0 \mathrm{Ma}$ and within the here analyzed C. cf.

645 notophthalmus in the Orinoco basin ranges between 3.4 to 5.9 My based on our 
646 calibration (Fig. 3) demonstrating long isolation between the allopatric species sensu 647 stricto.

648

649

Reticulata group

651

In the Reticulata group our analyses delimit all included valid species (Fig. 4).

The species $C$. reticulata and $C$. cyanonotus have in the present ichthyological definition very large distribution areas, the first covering virtually the whole of the westeast Amazon including Rio Branco and Amazonian Guiana, and the second the SW Amazon including upper Madeira. Our geographical sampling of both species in this study is still limited, but our analyses demonstrate that nominotypical $C$. reticulata from the Rio Negro (Rio Branco in our sampling) is delimited as a distinct species from the W-E Amazonian C. cf. reticulata with a divergence of $1.7 \mathrm{My}$. We have only been able to sample $C$. cf. cyanonotus from the upper Madeira and not the nominotypical $C$. cyanonotus from the Western Amazon sensu stricto in this study so the taxonomic composition of this species remains to be verified. Our analyses also find $C$. jegui and C. cf. jegui as distinct, non-sister species with a divergence of $2.8 \mathrm{My}$.

662

\section{Lacustris and Missioneira groups}

The Lacustris and Missioneira groups are sister-groups and are endemic to southern (sub)tropical South America. In our sampling this monophyletic group includes the largest number of described species (30 including two presently treated as synonyms) and also the densest geographical sampling (Figs 5-6). Our analyses delimit in these two species groups 31 to 38 species ( 25 to 28 and 6 to 10, respectively) and thus our delimitation analyses in this species group are in the best agreement with present classification among all Crenicichla species groups. The reason for this good correspondence is that these two groups have recently been revised in several studies

672 (Kullander \& Lucena, 2006; Casciotta et al., 2006; Lucena, 2007; Casciotta \& Almirón,

673 2008; Kullander, 2009; Piálek et al., 2010; Casciotta et al., 2010; Kullander \& Lucena,

674 2013; Casciotta et al., 2013; Mattos et al., 2014; Piálek et al., 2015; Řičan et al., 2017;

675 Piálek et al., 2019a,b). These two groups still include many putative undescribed 676 species, only some of which have been included in the present study (see references 
677 above). The only notable difference from the generally good correspondence between 678 morphological and molecular delimitations on this group is in the Missioneira group 679 from the Uruguay river basin where five morphologically very distinct sympatric species 680 (C. missioneira, C. minuano, C. tendybaguassu, C. hadrostigma, C. celidochilus) are 681 not monophyletic in our molecular analyses and nor are they monophyletic in the 682 genomic study of Burress et al. (2018b), probably because of their very young 683 divergence (Fig. 6). The second part of limited molecular delimitation is in the clade 684 including the Iguazú species (C. iguassuensis, C. tesay, C. tuca, C. tapii) and most 685 Middle Paraná species from the $C$. lacustris group. This clade demonstrates strong 686 mito-nuclear incongruence (Piálek et al., 2019a,b) which indicates that most of the 687 Middle Paraná species (all except $C$. ypo and $C$. hu) have had their mtDNA swept by 688 Iguazú species (Piálek et al., 2019a,b) which accounts for the lower delimitation 689 success in mtDNA in this clade.

In summary, our analyses delimit ten previously synonymized species as 692 genetically distinct (shown in orange in Figs 3-6) and at least 39 (i.e. those where all 3 693 delimitation analyses agree; 40-46 in individual delimitation analyses) previously 694 proposed putative new species as genetically distinct (shown in violet in Figs 3-6), most 695 of them in the Lugubris and Saxatilis groups (Teleocichla 2, Wallacii 5, Lugubris 16, 696 Saxatilis 12, Reticulata 2, Lacustris 2, Missioneira 0). Our analyses also identify 697 putative species without any previous reference (shown in red in Figs 3-6). These total 698 a minimum of 18 (mPTP analysis) while 37 are the shared minimum between the 699 GMYC and bPTP delimitations, and most analyses agree on 25 of these putative 700 species, most of them again in the Lugubris group (Teleocichla 1, Wallacii 0, Lugubris 701 12, Saxatilis 6-8, Reticulata 1, Lacustris 4, Missioneira 1). These delimited units 702 actually equal to one third of the presently known species diversity, a significant portion, 703 but their status is much less clear than for those delimited species that have previously 704 been identified as putative species by cichlid hobbyists. The species level status of 705 these delimited entities remains to be investigated with nDNA data and with careful 706 morphological study of both living and preserved specimens. 
708

709

710

711

712

713

714

715

716

717

718

719

720

721

722

723

724

725

726

727

728

729

730

731

732

733

734

735

736

737

\section{Underestimated Neotropical fish biodiversity}

The minimum percentage increase of possibly unrecognised species observed here in Crenicichla (65-121\%) significantly surpasses the conclusions of Reis et al. (2016), who estimated that $34-42 \%$ of Neotropical freshwater fishes remain undescribed. The percentage increase identified here varies widely between Crenicichla species group from $0 \%$ in the Missioneira and Macrophthalma groups, through $25-40 \%$ in the Lacustris group, $50-87 \%$ in the Reticulata group, $60-80 \%$ in Teleocichla, 68-168\% in the Saxatilis group, 125-200\% in the Wallacii group, and 158-241\% in the Lugubris group (Fig. 1). The numbers clearly indicate that the supposedly widely distributed species in the Reticulata, Wallacii, Saxatilis and especially Lugubris group have no foundation in the studied molecular markers. In agreement with Reis et al. (2016) the localization of the unrecognized diversity in Crenicichla is also in the Amazon basin, especially in its eastern portion and in the remaining two areas of the AOG core (Greater Amazonia) of South American ichthyological diversity.

The general explanations for the unrecognised diversity of Neotropical fishes stem largely from 1) lack of systematic sampling throughout the distibution of the given group and lack of sampling in areas of difficult access, (2) widespread taxa or heterogeneous taxa with insufficient or overwhelming amounts of museum material or improperly preserved material and information, and/or (3) cryptic or pseudocryptic (morphological differences apparent but overlooked) diversity in widespread species (Reis et al., 2016). Genetic data are an important instrument in uncovering cases of the latter. In Crenicichla the explanation for the underestimated diverstiy is the same with two additions, namely 1) limitations in available diagnostic characters due to predominant study of preserved specimens which have lost the diagnostic coloration pattern characters only present in live fishes (this is a specific cichlid problem among all other Neotropical fish groups), and 2) lack of acknowledgement in the professional ichthyological literature of the effort brought by the hobbyists, in this case the cichlid amateurs. As our study demonstrates, the majority of the genetically delineated putatively new species are not unexpected units (of these there are conservatively 25 
738 in our study), but rather previously proposed potentially undescribed species by the 739 cichlid hobbyists (of these there are conservativelly 39 in our study).

740 Therefore, we stress the conclusions of Reis (2013), who demonstrated that the

741 primary instruments for recognition, understanding, and conservation of Amazon basin

742 fishes is increasing expertise in fish taxonomy and systematics and we additionally

743 clearly demonstrate that DNA study and other genetic tools are powerful

744 complementary methods for uncovering fish diversity and highlighting groups in need of

745 taxonomic revisions.

746 Despite our wide ranging specimen sampling and potential for understanding of

747 Crenicichla diversity our study has one limiting factor and that is the use of a single 748 uniparentally inherited molecular marker (mtDNA cytb and ND2 loci). The potential 749 limitations for species delimitation using mtDNA have been discussed in literature (e.g., 750 Rannala \& Zang, 2003; Yang \& Rannala, 2010; Dupuis, Roe \& Sperling, 2012; Fujita et 751 al., 2012). The use of additional nuclear markers is generally recommended as the use 752 of these unlinked markers has the potential to improve the accuracy of phylogenetic 753 reconstructions and species delimitation. A study doing just that using the same 754 specimen sampling and the nDNA reduced genome representation ddRAD method is 755 currently in preparation and shows results that are highly congruent with the mtDNA 756 markers employed here.

757 In spite of having used only mtDNA loci, the majority of molecularly delimited 758 putative species are actually not previously unrecognized but previously synonymized 759 or already postulated species based on coloration patterns, morphological characters 760 and inferred endemism due to potential distribution barriers. All these additional data 761 support and reinforce the inference based on the mitochondrial markers.

762

763 Conclusions

764 We find a significantly underestimated species diversity in the largest 765 Neotropical cichlid genus Crenicichla. We found between 126 and 168 species-like 766 clusters, i.e. an average increase of species diversity of $65-121 \%$ and we found a high 767 degree of congruence between clusters derived from different methods of species 768 discovery. In spite of having used only mtDNA loci, the majority of molecularly delimited 
769 putative species are actually not previously unrecognized but previously synonymized

770 or already postulated putative species based on coloration patterns, morphological

771 characters and inferred endemism due to potential distribution barriers. All these

772 additional data support and reinforce the inference based on the mitochondrial markers.

773 Most of the newly delimited putative species are from the Amazon-Orinoco-Guiana 774 (AOG) core area (Greater Amazonia) of the Neotropical region, especially from the

775 Brazilian and Guiana shield areas of which the former is under the largest threat and

776 largest degree of environmental degradation of all the Amazon.

777

778

Acknowledgements

779 We thank Hernán Ortega (National University of San Marcos, Lima, Peru), Javier A. 780 Maldonado Ocampo (Pontificia Universidad Javeriana, Bogotá, Colombia), Cecilia 781 Rodríguez-Haro (Universidad Regional Amazónica IKIAM, Tena, Ecuador), and 782 Nadacion FUDECI (Venezuela) for supporting our research in their respective countries, 783 and to numerous cichlid hobby friends and research institutions (ANSP, Academy of 784 Natural Sciences of Philadelphia, Pennsylvania, USA; INPA, Instituto Nacional de 785 Pesquisas da Amazônia, Brasil) who helped us obtain a significant portion of the 786 material used in this study. Financial support was provided by The Czech Science 787 Foundation (GAČR) grant number 19-20012S and by Comisión de Investigaciones 788 Científicas de la provincia de Buenos Aires (CIC), Facultad de Ciencias Naturales y 789 Museo (UNLP) and Administración de Parques Nacionales. Computational resources were supplied by the Cipres server (https://www.phylo.org/) and the project "e-

791 Infrastruktura CZ" (e-INFRA LM2018140) provided within the program Projects of Large

792 Research, Development and Innovations Infrastructures.

793

794 
796

797

798

799

800

801

802

803

804

805

806

807

808

809

810

811

812 Bussing, W. A. (1976). Geographical distribution of the San Juan ichthyofauna of

813 Central America with remarks on its origin and ecology. In T. B. Thorson, (Ed.),

814 Investigations of the ichthyofauna of Nicaraguan lakes (pp. 157-175). University of

815 Nebraska, Lincoln, NE.

816 Bussing, W. A. (1985). Patterns of distribution of the Central American ichthyofauna. In

817 F. G. Stehli \& S. D. Webb (Eds.), The Great American Biotic Interchange (pp. 453-472).

818 Plenum Publishing Corporation, New York.

819 Carstens, B. C., \& Dewey, T. A. (2010). Species delimitation using a combined

820 coalescent and information-theoretic approach: an example from North American Myotis

821 bats. Systematic Biology, 59, 400-414. 
822 Casciotta, J., \& Almirón, A. (2008). Crenicichla tesay, a new species of cichlid 823 (Perciformes: Labroidei) from the río Iguazú basin in Argentina. Revue Suisse de 824 Zoologie, 115, 651-659.

825 Casciotta, J., Almirón, A., Aichino, D., Gómez, S., Piálek, L., \& Říčan, O. (2013).

826 Crenicichla taikyra (Teleostei: Cichlidae), a new species of pike cichlid from the middle 827 río Paraná, Argentina. Zootaxa, 3721, 379-386.

828 Casciotta, J., Almirón, A. E., Gómez, S. E. (2006). Crenicichla yaha sp. n. (Perciformes:

829 Labroidei: Cichlidae), a new species from the río Iguazú and arroyo Urugua-í basins, 830 northeastern Argentina. Zoologische Abhandlungen, 56, 107-112.

831 Casciotta, J., Almirón, A., Piálek, L., Gómez, S., \& Říčan, O. (2010). Crenicichla ypo 832 (Teleostei: Cichlidae), a new species from the middle Paraná basin in Misiones, 833 Argentina. Neotropical Ichthyology, 8, 643-648.

834 Drummond, A. J., \& Rambaut, A. (2007). BEAST: Bayesian evolutionary analysis by 835 sampling trees. BMC Evolutionary Biology, 7, 214.

836 Dupuis, J., Roe, A., \& Sperling, F. (2012). Multi-locus species delimitation in closely 837 related animals and fungi: one marker is not enough. Molecular Ecology, 21, 44228384436.

839 Edgar, R. C. (2004). MUSCLE: multiple sequence alignment with high accuracy and 840 high throughput. Nucleic Acids Research, 32, 1792-1797.

841 Fontaneto, D., Herniou, E. A., Boschetti, C., Caprioli, M., Melone, G., Ricci, C., \& 842 Barraclough, T. G. (2007). Independently evolving species in asexual bdelloid rotifers. 843 PLoS Biology, 5, e87.

844 Fujisawa, T., \& Barraclough, T. G. (2013). Delimiting species using single-locus data 845 and the Generalized Mixed Yule Coalescent approach: a revised method and evaluation 846 on simulated data sets. Systematic Biology, 62, 707-724. 
847 Fujita, M. K., Leache, A. D., Burbrink, F. T., McGuire, J. A., \& Moritz, C. (2012).

848 Coalescent-based species delimitation in an integrative taxonomy. Trends in Ecology 849 and Evolution, 27, 480-488.

850 Huelsenbeck, J. P., \& Ronquist, F. (2001). MRBAYES: Bayesian inference of 851 phylogenetic trees. Bioinformatics, 17, 754-755.

852 Ilves, K. L., Torti, D., \& López-Fernández, H. (2018). Exon-Based Phylogenomics

853 Strengthens The Phylogeny Of Neotropical Cichlids And Identifies Remaining

854 Conflicting Clades (Cichlomorphae: Cichlidae: Cichlinae). Molecular Phylogenetics and

855 Evolution, 118, 232-243.

856 Kearse, M., Moir, R., Wilson, A., Stones-Havas, S., Cheung, M., Sturrock, S., Buxton, S.,

857 Cooper, A., Markowitz, S., Duran, C., Thierer, T., Ashton, B., Mentjies, P., \&

858 Drummond, A. (2012). Geneious Basic: an integrated and extendable desktop software 859 platform for the organization and analysis of sequence data. Bioinformatics, 28, 16478601649.

861 Kullander, S. (1991). Crenicichla phaiospilus and C. percna, two new species of pike 862 cichlids (Teleostei: Cichlidae) from the Rio Xingu, Brazil. Ichthyological Explorations of 863 Freshwaters, 351-360.

864 Kullander, S. (1986). Cichlid Fishes of the Amazon River Drainage of Peru. Swedish 865 Museum of Natural History. Cichlids Amazon.

866 Kullander, S. (1988). Teleocichla, a new genus of South American rheophilic cichlid 867 fishes with six new species (Teleostei: Cichlidae). Copeia, 196-230.

868 Kullander, S. (1997). Crenicichla rosemariae, a new species of pike cichlid (Teleostei, 869 Cichlidae) from the upper Rio Xingu drainage, Brazil. Ichthyological Explorations of 870 Freshwaters, 7, 279-281.

871 Kullander, S.O. (1998). A phylogeny and classification of the neotropical Cichlidae 872 (Teleostei: Perciformes). In L.R. Malabarba, R.E. Reis, R.P. Vari, Z.M. Lucena \& C.A.S. 
873 Lucena (Eds.), Phylogeny and Classification of Neotropical Fishes (pp. 461-498).

874 EDIPUCRS, Porto Alegre.

875 Kullander, S. (2009). Crenicichla mandelburgeri, a new species of cichlid fish (Teleostei:

876 Cichlidae) from the Paraná river drainage in Paraguay. Zootaxa, 2006, 41-50.

877 Kullander, S. O., López-Fernández, H., \& van der Sleen, P. (2018). Family Cichlidae -

878 Cichlids: In P. van der Sleen \& J. S. Albert (Eds.), Field Guide to the Fishes of the

879 Amazon, Orinoco, and Guianas (pp. 359-385). Princeton University Press.

880 Kullander, S., \& Lucena, C. A. S. (2013). Crenicichla gillmorlisi, a new species of cichlid 881 fish (Teleostei: Cichlidae) from the Paraná river drainage in Paraguay. Zootaxa, 3641, 882 149-164.

883 Kullander, S. O., \& Lucena, C. A. Santos de. (2006). A review of the species of 884 Crenicichla (Teleostei: Cichlidae) from the Atlantic coastal rivers of southeastern Brazil 885 from Bahia to Rio Grande do Sul States, with descriptions of three new species. 886 Neotropical Ichthyology, 4, 127-146.

887 Lucena, C. A. S. (2007). Two new species of the genus Crenicichla Heckel, 1840 from 888 the upper rio Uruguay drainage (Perciformes: Cichlidae). Neotropical Ichthyology, 5, 889 449-456.

890 Mattos, José L., Schindler, I., Ottoni, F. P., \& Cheffe, M. M. (2014). A new species of 891 Crenicichla from the upper Rio das Antas basin, dos Patos lagoon system, southern 892 Brazil (Teleostei: Cichlidae). Vertebrate Zoology, 64, 35-42.

893 Monaghan, M. T., Wild, R., Elliot, M., Fujisawa, T., Balke, M., Inward, D. J. G., Lees, D.

894 C., Ranaivosolo, R., Eggleton, P., Barraclough, T. G., \& Vogler, A. P. (2009).

895 Accelerated species inventory on Madagascar using coalescent-based models of 896 species delineation. Systematic Biology, 58, 298-311.

897 Musilová, Z., Říčan, O., Říčanová, Š., Janšta, P., Gahura, O., \& Novák, J. (2015).

898 Phylogeny and historical biogeography of trans-Andean cichlid fishes (Teleostei:

899 Cichlidae). Vertebrate Zoology, 65, 333-350. 
900 Myers, G. S. (1966). Derivation of the freshwater fish fauna of Central America. Copeia, $9014,766-773$.

902 Nylander, J. A. A. (2004). MrModeltest v2 [Program distributed by the author].

903 Evolutionary Biology Centre, Uppsala University. Retrieved from

904 https://github.com/nylander/MrModeltest2

905 Piálek, L., Burress, E., Dragová, K., Almirón, A., Casciotta, J., \& Říčan, O. (2019a).

906 Phylogenomics of pike cichlids (Cichlidae: Crenicichla) of the C. mandelburgeri species

907 complex: rapid ecological speciation in the Iguazú River and high endemism in the

908 Middle Paraná basin. Hydrobiologia, 832, 355-375.

909 Piálek, L., Casciotta, J., Almirón, A., \& Řiččn, O. (2019b). A new pelagic predatory pike

910 cichlid (Teleostei: Cichlidae: Crenicichla) from the C. mandelburgeri species complex

911 with parallel and reticulate evolution. Hydrobiologia, 832, 377-395.

912 Piálek, L., Dragová, K., Casciotta, J., Almirón, A., \& Říčan, O. (2015). Description of two

913 new species of Crenicichla (Teleostei: Cichlidae) from the Lower Iguazú River with a

914 taxonomic reappraisal of $C$. iguassuensis, C. tesay and C. yaha. Historia Natural

915 (Tercera Serie), 5, 5-27.

916 Piálek, L., Říčan, O., Casiotta, J., \& Almirón, A. (2010). Crenicichla hu, a new species of

917 cichlid fish (Teleostei: Cichlidae) from the Paraná basin in Misiones, Argentina. Zootaxa, 918 2537, 33-46.

919 Piálek, L., Řiččan, O., Casciotta, J., Almirón, A., \& Zrzavý, J. (2012). Multilocus

920 phylogeny of Crenicichla (Teleostei: Cichlidae), with biogeography of the $C$. lacustris

921 group: Species flocks as a model for sympatric speciation in rivers. Molecular

922 Phylogenetics and Evolution, 62, 46-61.

923 Ploeg, A. (1991). Revision of the South American cichlid genus Crenicichla Heckel,

924 1840, with description of fifteen new species and consideration on species groups,

925 phylogeny and biogeography (Pisces, Perciformes, Cichlidae). University of Amsterdam,

926 Netherlands. 
927 Pons, J., Barraclough, T. G., Gomez-Zurita, J., Cardoso, A., Duran, D. P., Hazell, S., 928 Kamoun, S., Sumli, W. D., \& Vogler, A. P. (2006). Sequence-based species delimitation 929 for the DNA taxonomy of undescribed insects. Systematic Biology, 55, 595-609.

930 Powell, J. (2012). Accounting for uncertainty in species delineation during the analysis 931 of environmental DNA sequence data. Methods in Ecology and Evolution, 3, 1-11.

932 Rambaut, A., Drummond, A. J., Xie, D., Baele, G., \& Suchard, M. A. (2018). Posterior 933 summarisation in Bayesian phylogenetics using Tracer 1.7. Systematic Biology, syy032.

934 Rannala, B., \& Zang, Z. (2003). Bayes estimation of species divergence times and 935 ancestral population sizes using DNA sequences from multiple loci. Genetics, 164, 936 1645-1656.

937 Reis, R. E. (2013). Conserving the freshwater fishes of South America. International 938 Zoo Yearbook, 47, 65-70.

939 Reis, R. E., Albert. J. S., Di Dario, F., Mincarone, M. M., Petry, P., \& Rocha, L. A. (2016). 940 Fish biodiversity and conservation in South America. Journal of Fish Biology, 89, 12-47.

941 Reis, R. E., Kullander, S. O., \& Ferraris Jr., C. J. (2003). Check list of the freshwater 942 fishes of South and Central America. Edipucrs, Porto Alegre, Brazil.

943 Ronquist, F., \& Huelsenbeck, J. P. (2003). Mrbayes 3: Bayesian phylogenetic inference 944 under mixed models. Bioinformatics, 19, 1572-1574.

945 Říčan, O., Říčanová, Š. Dragová, K., Piálek, L., Almirón, A., \& Casciotta, J. (2019).

946 Species diversity in Gymnogeophagus (Teleostei: Cichlidae) and comparative

947 biogeography of cichlids in the Middle Paraná basin, an emerging hotspot of fish 948 endemism. Hydrobiologia, 832, 331-354.

949 Říčan, O., Almirón, A., \& Casciotta, J. (2017). Rediscovery of Crenicichla yaha 950 (Teleostei: Cichlidae). Ichthyological Contributions of PecesCriollos, 50, 1-8. 
951 Říčan, O., Piálek, L., Dragová, K., \& Novák, J. (2016). Diversity and evolution of the 952 Middle American cichlid fishes (Teleostei: Cichlidae) with revised classification.

953 Vertebrate Zoology, 66, 1-102.

954 Říčan, O., Piálek, L., Zardoya, R., Doadrio, I., \& Zrzavý, J., (2013). Biogeography of the 955 Mesoamerican Cichlidae (Teleostei: Heroini): colonization through the GAARlandia land 956 bridge and early diversification. Journal of Biogeography, 40, 579-593.

957 Říčan, O., Zardoya, R., \& Doadrio, I. (2008). Phylogenetic relationships of Middle 958 American cichlids (Cichlidae, Heroini) based on combined evidence from nuclear genes, 959 mtDNA, and morphology. Molecular Phylogenetics and Evolution, 49, 941-957.

960 Stamatakis, A. (2014). RAxML version 8: a tool for phylogenetic analysis and post961 analysis of large phylogenies. Bioinformatics, 30, 1312-1313.

962 Stawikowski, R., \& Werner, U. (2004). Die Buntbarsche Amerikas. Band 3:

963 Erdfresser,Hecht- und Kammbuntbarsche. Eugen Ulmer, Stuttgart.

964 Swofford, D. L. (2003). PAUP*. Phylogenetic analysis using parsimony ( ${ }^{*}$ and other 965 methods) Version 4 [Computer Programme]. Sinauer Associates, Sunderland, MA.

966 Van der Sleen, P., \& Albert, J. S. (2018). Field Guide to the Fishes of the Amazon, 967 Orinoco, and Guianas. Princeton University Press.

968 Villesen, P. (2007). FaBox: an online toolbox for FASTA sequences. Molecular Ecology 969 Notes, 7, 965 - 968. DOI: 10.1111/j.1471-8286.2007.01821.x

970 Vuataz, L., Sartori, M., Wagner, A., \& Monaghan, M. T. (2011). Toward a DNA 971 taxonomy of Alpine Rhithrogena (Ephemeroptera: Heptageniidae) using a mixed Yule972 coalescent analysis of mitochondrial and nuclear DNA. PLOS One, 6, e19728.

973 Yang, Z., \& Rannala, B. (2010). Bayesian species delimitation using multilocus 974 sequence data. Proceedings of the National Academy of Sciences of the United States 975 of America, 107, 9264-9269. 
976 Zhang, J., Kapli, P., Pavlidis, P., \& Stamatakis, A. (2013). A general species delimitation

977 method with applications to phylogenetic placements. Bioinformatics, 29, 2869-2876.

978

979

980

981

982

983

984

985 Figure legends:

986 Fig. 1. Map of sampling locations shown by red dots on a relief map of South America.

987 One dot may represent several localities in close proximity.

988 Fig. 2. Maximum clade credibility chronogram from 10,000 posterior trees generated 989 using Beast collapsed to show species groups (same tree as in Figs 3-6). Dataset 990 comprised of 591 unique haplotypes (from a total of 681 samples) of Crenicichla

991 (including Teleocichla) cytb and ND2 sequences (2163 aligned base pairs). Bayesian 992 posterior probabilities above 0.95 are shown as black points on nodes. Numbers at 993 nodes show ages of divergence for selected nodes. Grey bars at nodes show 95\% HPD

994 intervals for reconstructed ages of nodes. Numbers behind species groups are sampled 995 valid species / delimited species (range between methods based on Figs 3-6). Colors of 996 species groups show percentual increase of delimited species (average; based on color 997 scale scale to the left) compared to presently valid number of species in a given species 998 group.

999 Fig. 3. First part of the maximum clade credibility chronogram from 10,000 posterior 1000 trees generated using Beast (same tree as Fig. 2) showing the Wallacii and Lugubris 1001 species groups and Telecichla. Bayesian posterior probabilities above 0.95 are shown 
1002 as black points on nodes. Numbers at nodes show ages of divergence for selected 1003 nodes. Point estimate species delimitations are shown by method as coloured boxes. 1004 Colour of the box shows correspondence to presently valid classification: Green: match 1005 with a presently recognized valid species; Orange: delimited taxon is currently treated 1006 as a synonym of a valid species; Violet: delimited taxon has been proposed in literature 1007 as a putative new species; Red: newly delimited taxon not previously suggested in 1008 literature; Grey: conservative delimitation compared to valid classification (i.e. contains 1009 more than one valid species). Abbreviations: sv=number of sampled valid species, $1010 \mathrm{e}=$ estimated species based on the delimitations, $\mathrm{t}=$ total known valid species, $1011 \mathrm{~T}=$ extrapolated total species based on ratio of included valid species in analysis and all 1012 valid species known. mPTP analysis delimited 126 species, GMYC 153 species and 1013 bPTP 168 species in the whole species tree.

1014 Fig. 4. Second part of the maximum clade credibility chronogram from 10,000 posterior 1015 trees generated using Beast (same tree as Fig. 2) showing the Saxatilis, Reticulata and 1016 Macrophthalma species groups.

1017 Fig. 5. Third part of the maximum clade credibility chronogram from 10,000 posterior 1018 trees generated using Beast (same tree as Fig. 2) showing the Lacustris species group.

1019 Fig. 6. Fourth part of the maximum clade credibility chronogram from 10,000 posterior 1020 trees generated using Beast (same tree as Fig. 2) showing the Missioneira species 1021 group.

1022 Fig. S1. RAxML phylogeny of Crenicichla (including Teleocichla) based on same 1023 concatenated cytb plus ND2 dataset as Figs. 2 and 3 showing relationships among 1024 main groups with bootstrap support values for nodes in red.

1025 Fig. S2. RAxML phylogeny of Crenicichla (including Teleocichla) as in Fig. S1 showing 1026 the complete tree with bootstrap support values for nodes in red. 
Figure 1

Map of sampling locations shown by red dots on a relief map of South America.

One dot may represent several localities in close proximity. 


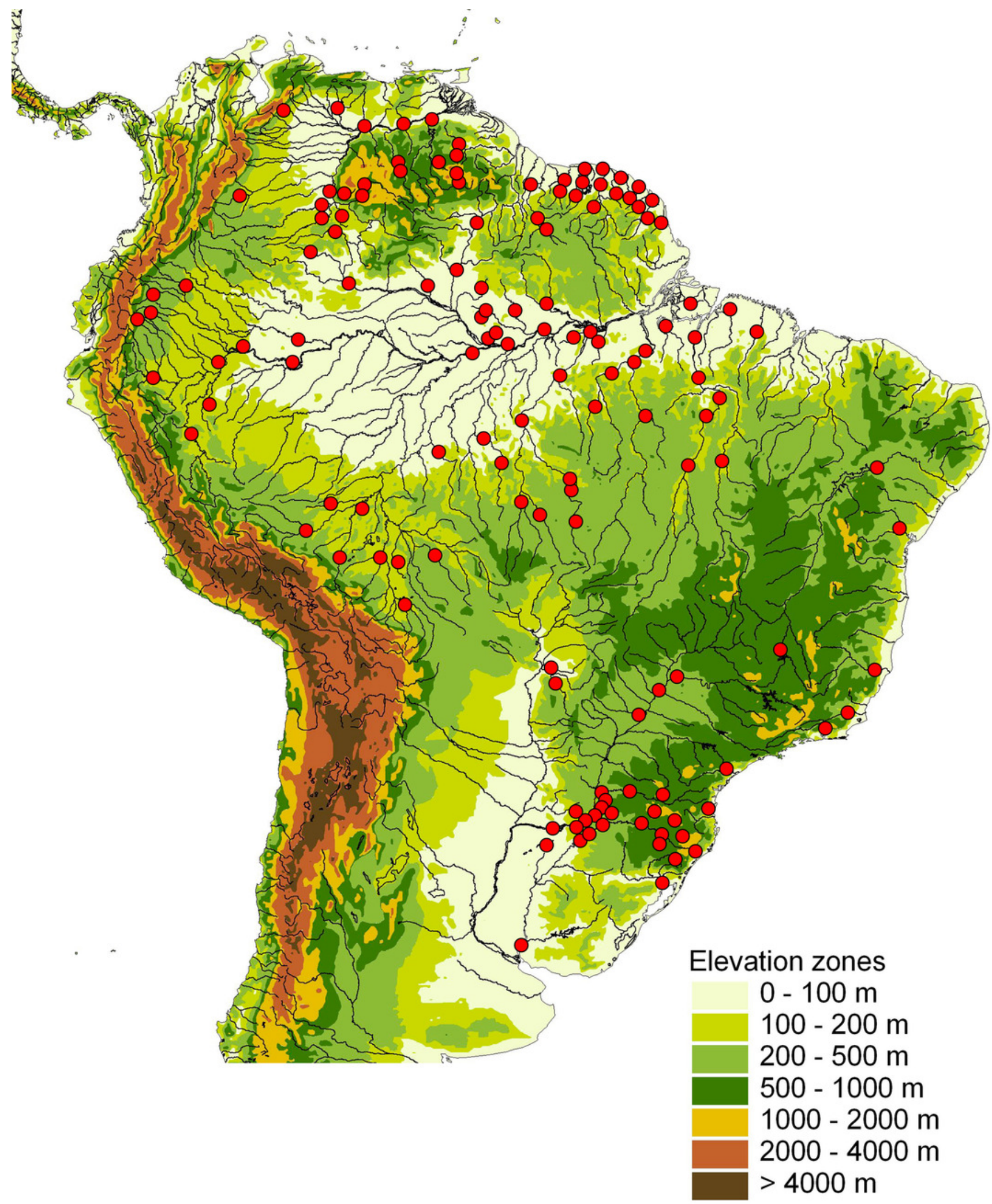




\section{Figure 2}

Maximum clade credibility chronogram from 10,000 posterior trees generated using Beast collapsed to show species groups (same tree as in Figs 3-6).

Dataset comprised of 591 unique haplotypes (from a total of 681 samples) of Crenicichla (including Teleocichla) cytb and ND2 sequences (2163 aligned base pairs). Bayesian posterior probabilities above 0.95 are shown as black points on nodes. Numbers at nodes show ages of divergence for selected nodes. Grey bars at nodes show 95\% HPD intervals for reconstructed ages of nodes. Numbers behind species groups are sampled valid species / delimited species (range between methods based on Figs 3-6). Colors of species groups show percentual increase of delimited species (average; based on color scale scale to the left) compared to presently valid number of species in a given species group. 


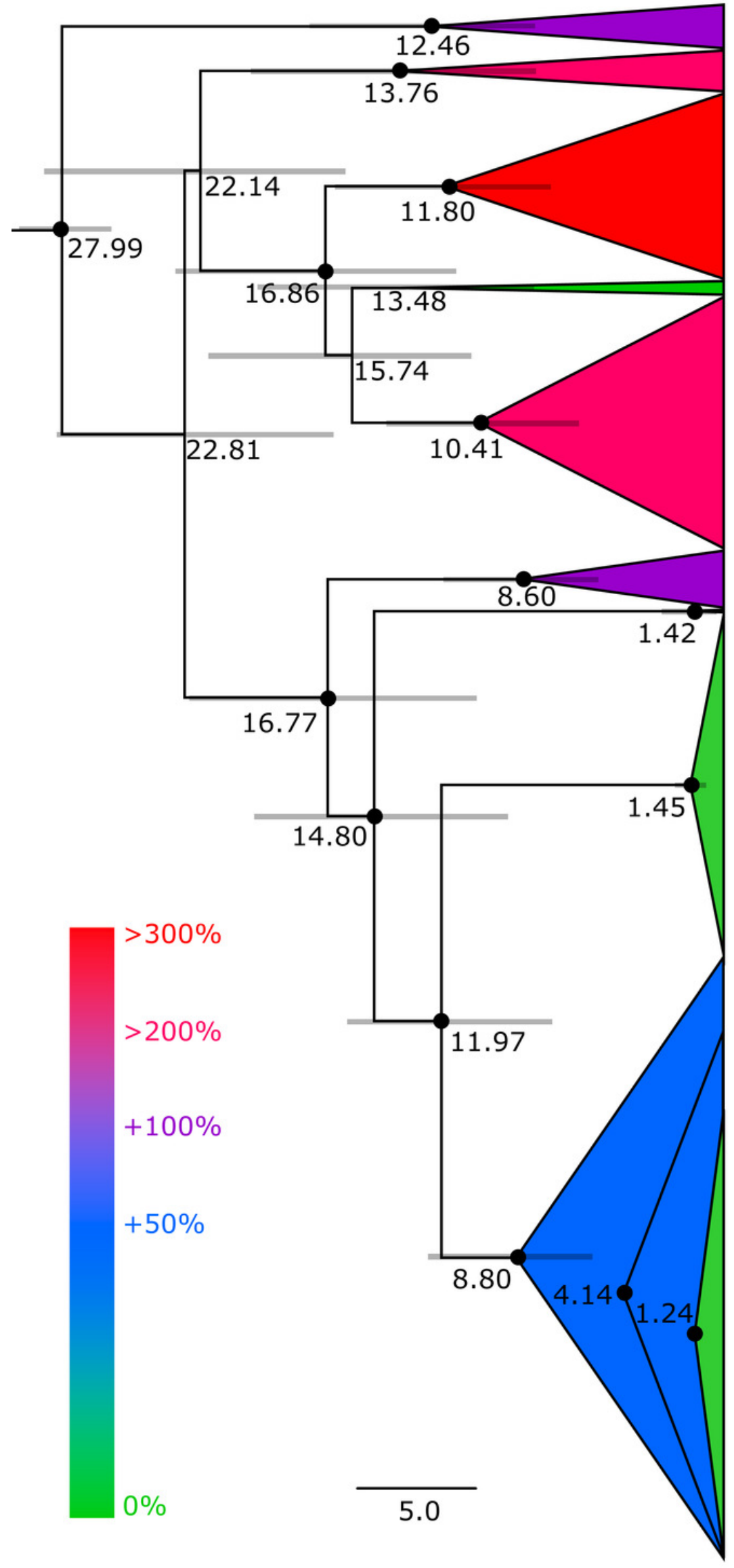

Teleocichla (5/8-9)

Wallacii (4/9-12)

Lugubris (8/27-37)

Lugubris

(Acutirostris) (4/4)

Saxatilis (19/32-51)

Reticulata (8/12-15)

Macrophthalma (1/1-2)

Missioneira (8/6-10)

Lacustris (20/25-28)

Middle Paraná (10/13-15)

Iguazú clade (7/8-10) 


\section{Figure 3}

First part of the maximum clade credibility chronogram from 10,000 posterior trees generated using Beast (same tree as Fig. 2) showing the Wallacii and Lugubris species groups and Telecichla.

Bayesian posterior probabilities above 0.95 are shown as black points on nodes. Numbers at nodes show ages of divergence for selected nodes. Point estimate species delimitations are shown by method as coloured boxes. Colour of the box shows correspondence to presently valid classification: Green: match with a presently recognized valid species; Orange: delimited taxon is currently treated as a synonym of a valid species; Violet: delimited taxon has been proposed in literature as a putative new species; Red: newly delimited taxon not previously suggested in literature; Grey: conservative delimitation compared to valid classification (i.e. contains more than one valid species). Abbreviations: $s v=$ number of sampled valid species, e=estimated species based on the delimitations, $\mathrm{t}=$ total known valid species, $\mathrm{T}=$ extrapolated total species based on ratio of included valid species in analysis and all valid species known. mPTP analysis delimited 126 species, GMYC 153 species and bPTP 168 species in the whole species tree. 


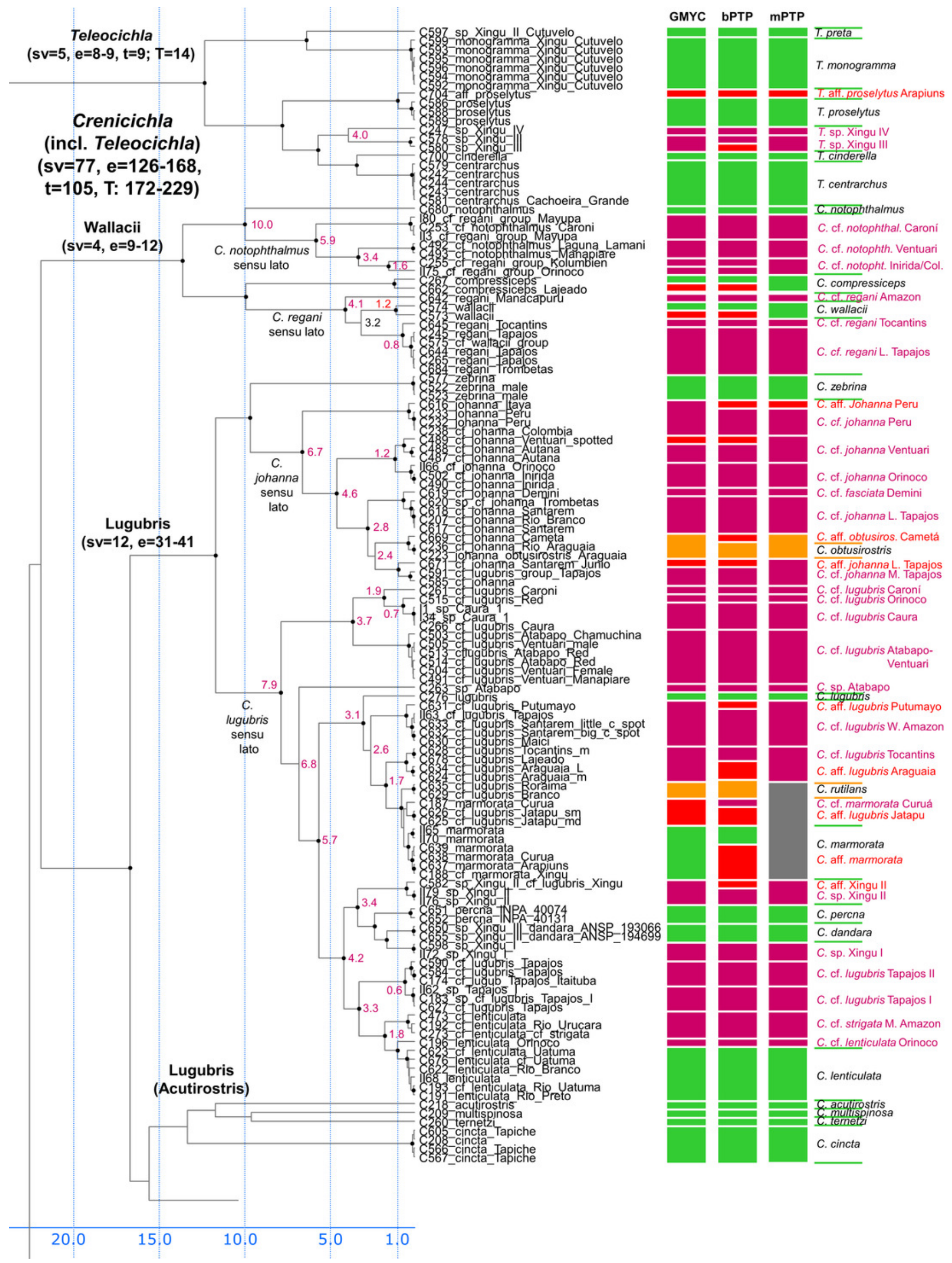


Figure 4

Second part of the maximum clade credibility chronogram from 10,000 posterior trees generated using Beast (same tree as Fig. 2) showing the Saxatilis, Reticulata and Macrophthalma species groups. 


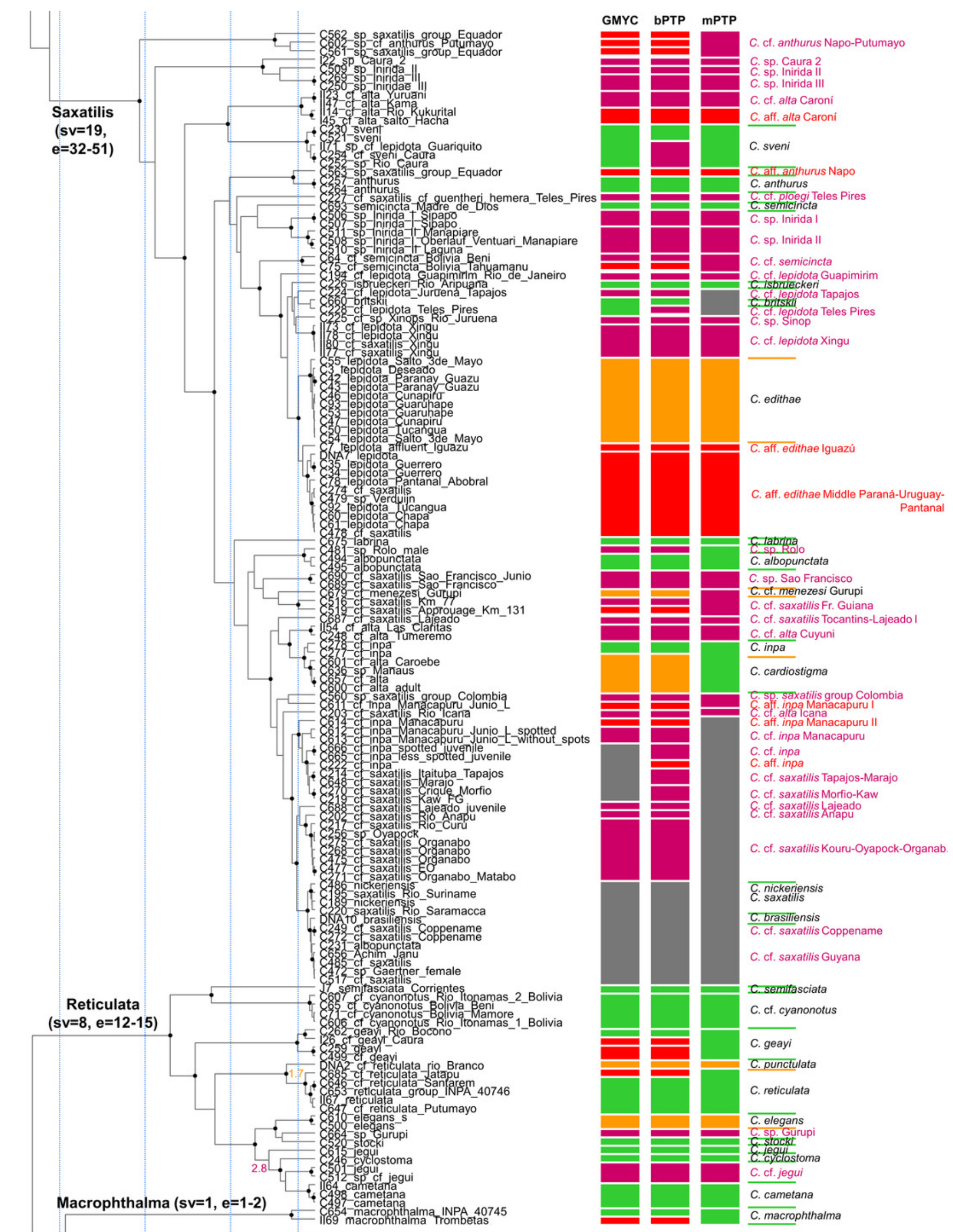


Figure 5

Third part of the maximum clade credibility chronogram from 10,000 posterior trees generated using Beast (same tree as Fig. 2) showing the Lacustris species group. 


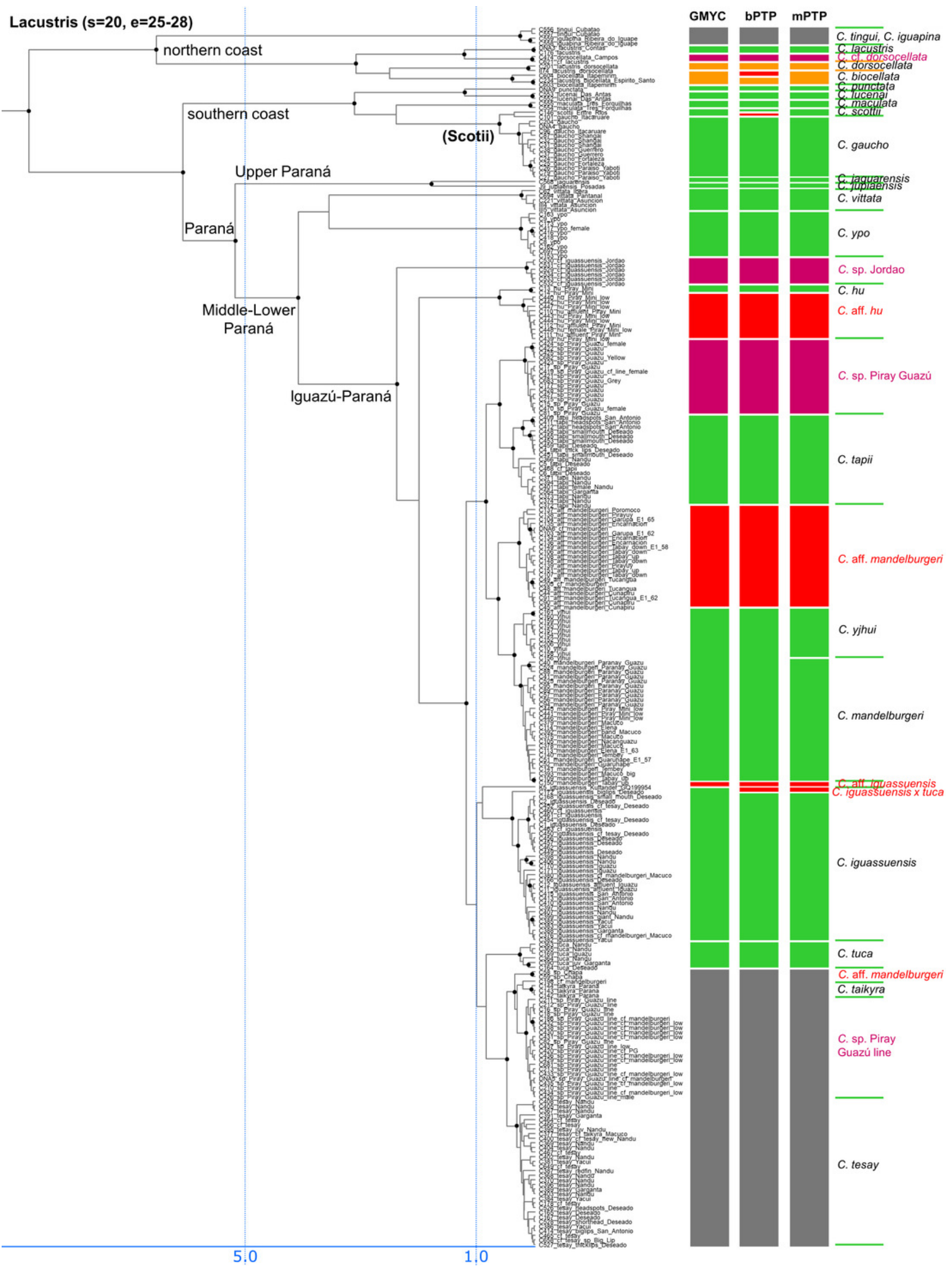


Figure 6

Fourth part of the maximum clade credibility chronogram from 10,000 posterior trees generated using Beast (same tree as Fig. 2) showing the Missioneira species group. 


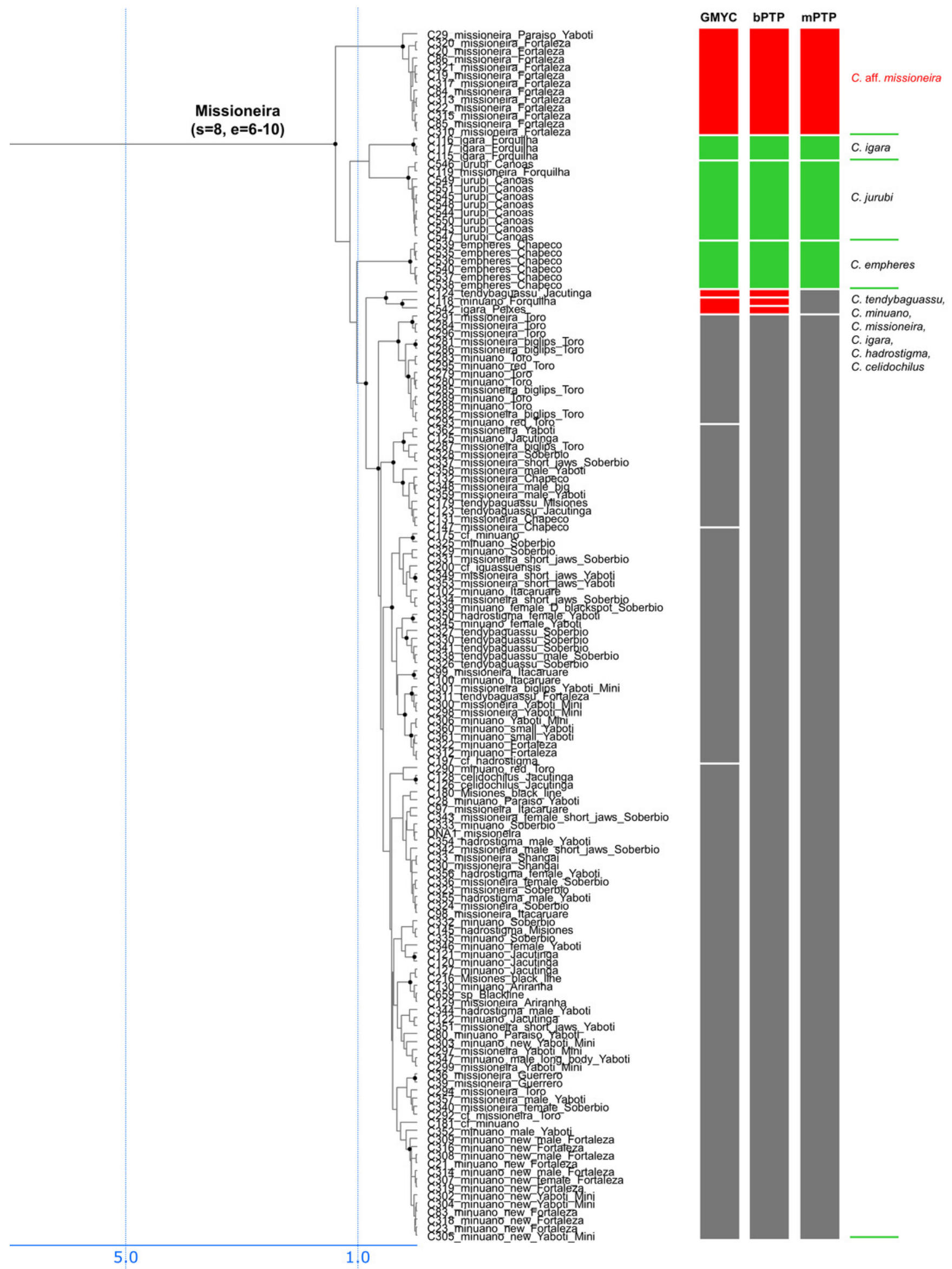

